\title{
Information on the Quality of Substance for the Preparation of Pharmaceutical Drugs in Terms of Hospital Pharmacy
}

\author{
Marija Dj. Jovović ${ }^{1}$, Maja M. Ribar ${ }^{1}$ \\ ${ }^{1}$ Central Pharmacy, Clinical Centre of Serbia, Belgrade, Serbia
}

\section{SUMMARY}

Explanation the topic The pharmaceutical activity is the activity of public or social and special interest, because it is a direct function of health care.

Topic positioning and discussion The aim of this paper is to highlight the importance of ensuring the quality of pharmaceutical substances that supplies hospitals, which are used for production of galenic and magistral drugs.

Conclusion Compliance with national legislation, as well as establishing compliance prescribed by the European legislation in the field of drug development is binding. Therefore, all manufacturers of drugs and/or active pharmaceutical ingredients must apply quality standards prescribed by the European Pharmacopoeia in order to develop, manufacture and sales of medicines. When it comes to the quality of pharmaceutical ingredients for the production of drugs in the pharmacy, pharmacies especially in residential institutions in our country is permanently done by harmonizing national legislation in order to improve conditions for the preparation and production of galenic drugs in terms of inpatient health institutions performed in a manner that is prescribed by international regulations. This requires the adaptation of institutions, including fundamental changes in competence as national professional and administrative and regulatory rules that apply to state- and private sectors.

Keywords: pharmaceutical drugs, hospital pharmacy, quality of substances

\section{EXPLANATION THE TOPIC}

The pharmaceutical activity is the activity of public or social and special interest, because it is a direct function of health care. Health care is the promotion, preservation of health, early and adequate treatment of the disease. This is achieved by providing quality health services in general.

Providing quality health services at the hospital is based on the direct cooperation of doctors, pharmacists and patients. The supply of medicines and medical devices and manufactured drugs (galenic and magistral drugs), allows the preservation of health and prevention of disease development, which constitute the core pharmaceutical business, as part of health services [1].

\section{TOPIC POSITIONING AND DISCUSSION}

The aim of this paper is to highlight the importance of ensuring the quality of pharmaceuti- 
cal substances that supplies hospitals, which are used for production of galenic and magistral drugs.

\section{Creating galenic and magistral drugs}

Galenic drug for use in human medicine is a drug which is produced in a galenic pharmacy laboratory of pharmaceutical ingredients (active and/or auxiliary) in accordance with the recipes (magistral formula, etc.) which, at the joint proposal of physicians and pharmacists from practice confirms Agency medicines and Medical Devices Agency of Serbia, and is intended for the issuance of the final user of pharmacy in accordance with the regulations governing pharmaceutical activity [2]. Magistral drug for use in human medicine is drug which is produced in pharmacy laboratory for a particular patient or group of patients $(\mathrm{Ph}$ Eur 7) according to the physician recipe or according to standard recipes from professional pharmaceutical manuals, or drug remanded when to achieve a therapeutic effect on the market available as an industrially manufactured or as galenic medicine of the same composition of active and additional pharmaceutical ingredients, with a certain strength or pharmaceutical form, made in the laboratory and pharmacy issued immediately after preparation, and no later than 24 hours [2].

Pharmaceutical substances are used to create the galenic and the magistral drug that may be active or auxiliary pharmaceutical ingredients. Active Pharmaceutical Ingredient-API is any pharmaceutical ingredient or the combination of pharmaceutical ingredients used in the production or manufacture of a medicament, which is the active ingredient of the drug and has the pharmacological activity of, or otherwise has a direct impact in the diagnosis, treatment, alleviation, care, or prevention of a disease affecting the structure or body functioning [2].

Excipient is a pharmaceutical ingredient which is used in the manufacture or preparation of a medicament, the active ingredient is not already provided with the preparation of a suitable pharmaceutical form of the drug, as well as demanding physicochemical and biopharmaceutical properties of the medicinal product (Ph Eur 8) [2,3].

\section{Quality Control}

All starting pharmaceutical ingredients and other materials that are used in the preparation of galenic and magistral drugs must go through a complex process of quality control. Testing laboratories and drug control perform these tasks in the hospital pharmacy galenic laboratory.

To procure pharmaceutical substances for galenic laboratory, an expert for quality assurance must set the quality requirements for pharmaceutical ingredients that will compete in the implementation of public procurement, according to the existing legislation $[2,4]$.

States, including the Republic of Serbia, harmonize national rules relating to the production and transport of drugs to the regulations that exist in the European Union.

The three most developed regions of the world: EU, US and Japan in 1990 formed the International Conference on Harmonization (ICH) as a permanent body with the aim of designing, planning and coordinating the process of harmonization directives in the field of putting drugs on the market. Three key elements are the guidelines that govern all pharmaceutical association of the world, such as: quality, safety and efficacy of drugs [5]. In the Republic of Serbia, quality requirements are set in accordance with regulations established by the Ministry of Health of the Republic of Slovenia, which are harmonized with the guidelines and directives of the European Parliament and of the Council of the EU relating to drugs for use in human medicine $[6,7,8]$.

The legislation of the Republic of Serbia, namely the Ministry of Health of the Republic of Slovenia regulate the field of pharmaceutical ingredients quality as well as regulations for the production of drugs in accordance with the regulations of the RS, which are: Law on Medicines and Medical Devices “Official Gazette of RS” No. 30/10 and 107/12; Regulation on conditions for the production of galenic drugs “Official Gazette of RS” No.10/12; Ordinance amending Rules of pharmaceutical drugs used in human medicine "Official Gazette of RS” No. 101/14; Guidelines on Good Manufacturing Practices "Official Gazette of RS” No. 28/08; Guidelines of Good Laboratory Practice “Official Gazette of RS” No. 28/08.

EU legislation in the field of active pharmaceutical ingredients includes: Declaration of the European Parliament on the API; 
Changes/amendments to legislation; Directive 2001/83 with amendments; Directive 2003/94; EU GMP (Good Manufacturing Practice in European Union); European Pharmacopoeia (Ph Eur.).

Directive 2001/83 as amended provides important guidelines for the quality of pharmaceutical substances used in making medicines [6]. Article 46 of the Directive states: A permit holder is responsible for production, to ensure a minimum: (f) Compliance with the principles and guidelines of GMP Good Manufacturing Practice (DPP Good Manufacturing Practice) and used for input material only one API (Active Pharmaceutical Ingredients), which are produced in accordance with the GMP guidelines for input materials [7]. The same requirement is in Directive 2003/94/EC.

The quality of the initial pharmaceutical ingredients in the preparation of pharmaceutical drugs is determined by an expert who participated in the preparation-making, it is always a qualified pharmacist (relevant specialty). The quality is not determined by one of ordinary skill products that perform tasks of secondary packaging or distributing pharmaceutical ingredient. All of the pharmaceutical ingredients are in the original manufacturer's package. The manufacturer may be primary (the one who does the synthesis of ingredients) and secondary (who repackages pharmaceutical ingredient). Most repackaged pharmaceutical ingredients are on the market. Secondary production must meet all of the above conditions. They must be met by all parts of the EU GMP (Part II). The legal entity that performs these tasks must have a license for the production of active pharmaceutical ingredients EU GMP Certificate [9].

Repackaged pharmaceutical substance is a new product, so it must have final control of repackaged API. The control laboratory for the release of repackaged pharmaceutical substances on the market must also have the EU GMP Certificate because: Guidelines for Good Manufacturing Practices, part 1 ("Official Gazette of RS“, No. 28/2008), state: Basic requirements for drug production are: Good Manufacturing Practice relating to the production and quality control [9]. Guidelines for Good Manufacturing Practices, part 2 ("Official Gazette of RS“, No. 86/2010), state: "Production" means all operations of receipt of materials, repackaging, labelling, quality control, release, storage, distribution and their control [10].

The pharmaceutical ingredient to be supplied for the drug making must have a Certificate of Analysis (CoA) in addition to the above documents. Certificate of analysis is the identification card of pharmaceutical ingredients, must have all of the following characteristics listed in the specification of produced pharmaceutical ingredient. Compliance with the specification means that the active pharmaceutical ingredient meets the above criteria for the acceptance of results. Criteria for result acceptance are the numeric values that represent the extent to which obtained result must be found, the maximum or minimum allowed value that obtained result can have.

The minimum requirement given in its specification for the quality of pharmaceutical ingredients is the one prescribed by the Pharmacopoeia which the pharmaceutical substance is declared. This is true for pharmaceutical substances that are officinal per Pharmacopoeia (Ph Eur pharmacopoeia or the EU) $[9,10]$.

Tests that are found in the Specification:

1. Appearance where qualitative characteristics are listed (e.g. solid, liquid, crystal, amorphous substance, etc.);

2. Identification of the specifications to which the allegations identification tests, which can distinguish between substances with similar structures, which may be present in the sample;

3. Determination of the content is done by using specific methods, and usually it is a method that can monitor stability;

4. Examination of impurities includes qualitative and quantitative analysis of organic and inorganic impurities and residual solvents.

There are other tests that can be found in the specification such as: Physicochemical characteristics $(\mathrm{pH}$, temperature of melting, refractive index, etc.); Particle size; Polymorphism (with substances which have more than one crystal form); Tests that are performed on pharmaceutical substances which have chiral properties; Determination of water content; Inorganic impurities originating from the catalyst; microbiological purity test which includes the determination of total aerobic microorganisms, fungi, mould and absence of certain specific bacteria (e.g. Staphylococcus aureus, Escherichia coli, Pseudomonas aeruginosa)[3]. 
The official standards are published by the European Pharmacopoeia and provide legal and scientific basis for quality control during the development, production (manufacture) and transport of drugs. European pharmacopoeia in checking the quality of drugs is used by manufacturers of drugs and health authorities of all European countries [11]. European Pharmacopoeia, which is sponsored by the European Directorate for the Quality of Medicines and Health Care (EDQM) is considered a key entity, i.e., an institution that sets standards for drugs.

\section{CONCLUSION}

Compliance with national legislation, as well as establishing compliance prescribed by the European legislation in the field of drug development is binding. Therefore, all manufacturers of drugs and/or active pharmaceutical ingredients must apply quality standards prescribed by the European Pharmacopoeia in order to develop, manufacture and sales of medicines. When it comes to the quality of pharmaceutical ingredients for the production of drugs in the pharmacy, pharmacies especially in residential institutions in our country is permanently done by harmonizing national legislation in order to improve conditions for the preparation and production of galenic drugs in terms of inpatient health institutions performed in a manner that is prescribed by international regulations. This requires the adaptation of institutions, including fundamental changes in competence as national professional and administrative and regulatory rules that apply to state- and private sectors.

\section{REFERENCES}

1. Kastratovic D, Jovovic M. Ribar M. Galen magistral preparations - hospital use - our experience. Pharmaca Serbica, 2009; 1(3-4):27-28.

2. Zakon o lekovima i medicinskim sredstvima "Sl. gl. RS", br. 30/2010, http: / / www.zdravlje.gov.rs/showpage.php?id=136

3. European Pharmacopeia (2011) $7^{\text {th }}$ edn. Council of Europe, Strasburg.

4. Pravilnik o uslovima za izradu galenskih lekova. Sluzbeni glasnik Republike Srbije, 10/2012.

http: / / www.zdravlje.gov.rs/showpage.php?id=140

5. ICH Harmonised Tripartite Guideline: Good Manufacturing Practice Guide for Active Pharmaceutical Ingredients Q7, 10. November 2000.
6. Directive 2001/83/EC of the European Parliament and of the Council of 6 November 2001 on the Community Code Relating to Medicinal Products for Human Use, Official Journal L - 211, 28/11/2004, 67-128.

7. European Commission Health and Consumers Directorate-general. Basic Requirements for Active Substances used as Starting Materials.

http: / /ec.europa.eu/health/files/eudralex/vol-4 /2014-08_gmp_part1.pdf

8. European Commission. EudraLex Volume 1 - Pharmaceutical Legislation Medicinal Products for Human Use.

http://ec.europa.eu/health/documents/eudralex/ vol-1/index_en.htm

9. European Commission. Quality of medicines and Good Manufacturing Practices (GMP).

http://ec.europa.eu/health/human-use/quality/ index_en.htm

10. Smernice Dobre proizvođačke prakse, 1 deo . Sluzbeni glasnik Republike Srbije: 28/2008.

11. Pejović G, Marinković V, Filipović Tasić Lj. Analiza uticaja farmaceutske legistlative $u$ unapređenju infrastrukture kvaliteta u Srbiji, Savremene tehnologije, 2012;1(2): 58-66. (in Serbian) 


\title{
Informacija o kvalitetu farmaceutskih supstanci za izradu lekova u uslovima bolničke apoteke
}

\author{
Marija Dj. Jovović́ ${ }^{1}$, Maja M Ribar ${ }^{1}$ \\ ${ }^{1}$ Centralna apoteka, Klinički Centar Srbije, Beograd, Srbija
}

\section{KRATAK SADRŽAJ}

Objašnjenje teme Farmaceutska delatnost predstavlja delatnost od opšteg, ali i posebnog društvenog interesa, jer je u direktnoj funkciji zdravstvene zaštite.

Pozicioniranje teme i diskusija Cilj rada je da ukaže na važnosti obezbeđivanja kvaliteta farmaceutskih supstanci kojima se snabdeva bolnica, a koji služe za izradu galenskih i magistaralnih lekova.

Zaključak Poštovanje zakonske regulative Republike Srbije, kao i uspostavljanje usaglašenosti koje propisuje Evropska regulativa u oblasti izrade lekova je obavezujuće. Stoga, svi proizvođači lekova i/ili aktivnih farmaceutskih supstanci moraju primenjivati standarde kvaliteta propisane Evropskom farmakopejom u cilju izrade, proizvodnje i prometa lekova.Kada je u pitanju kvalitet farmaceutskih supstanci za izradu lekova u uslovima apoteke, posebno apoteke u stacionarnim ustanovama, u našoj sredini se permanentno vrši usklađivanje nacionalnog zakonodavstva kako bi se unapredili uslovida se priprema i izrada galenskih lekova u uslovima stacionarnih zdravstvenih ustanova vrši na način koji je propisan međunarodnim propisima. To zahteva i prilagođavanje institucija, uključujući fundamentalne promene u nadležnostl, kako nacionalnih stručnih tako i administrativnih i regulatornih propisa koji važe kako u državnom tako i u privatnom sektoru.

Ključne reči: lekovi, bolnička farmacija, kvalitet farmaceutskih substanci 